University of Nebraska - Lincoln

DigitalCommons@University of Nebraska - Lincoln

Studies from the Zoological Laboratory: The University of Nebraska

8-1-1895

\title{
A New Method for the Quantitative Determination of Plankton Hauls
}

Henry B. Ward

University of Nebraska - Lincoln

Follow this and additional works at: https://digitalcommons.unl.edu/zoolabstud

Part of the Aquaculture and Fisheries Commons, Terrestrial and Aquatic Ecology Commons, and the Zoology Commons

Ward, Henry B., "A New Method for the Quantitative Determination of Plankton Hauls" (1895). Studies from the Zoological Laboratory: The University of Nebraska. 11.

https://digitalcommons.unl.edu/zoolabstud/11

This Article is brought to you for free and open access by the Parasitology, Harold W. Manter Laboratory of at DigitalCommons@University of Nebraska - Lincoln. It has been accepted for inclusion in Studies from the Zoological Laboratory: The University of Nebraska by an authorized administrator of DigitalCommons@University of Nebraska Lincoln. 


\section{A NEW METHOD FOR THE QUANTITA- TIVE DETERMINATION OF PLANKTON HAULS.}

Henry B. Ward, Ph. D., Lincoln, Neb.

Only two methods of estimating the quantity of plankton obtained in a haul of the vertical net are known to me. These two may be called the volumetric and the gravimetric. Both have been used by observers in various parts of the world, but so far as I know have never been comparatively tested in order to ascertain the relative value of results obtained by the two. The experience of the past year has shown some disadvantages in the first method, while the second has certain evident objections which rendered its employment in this case out of the question. In the course of the work outlined in another paper (Ward 95) I worked out a modification of the volumetric method, or rather, perhaps, a way of combining the two methods so as to control and correct each other; this combined method is briefly outlined in the following, but for its better understanding a short account of the two previously existing methods is prefixed.

The volumetric method of measuring the plankton is as follows : The material obtained in a single haul of the vertical net is preserved in toto under precautions which prevent any appreciable loss* ; this mass is brought with care into an accurately graduated glass tube and allowed to settle twenty-four hours; at the end of that time the exact volume in cubic centimetres is read from the scale, or estimated if the upper surface is not perfectly horizontal. This approximation can be made sufficiently accurately, but I have found by a series of experiments, that the amount obtained by these measurements is variable and depends on several conditions. In the first place it fluctuates with the size of the tube. In the larger tube the plankton settles more thoroughly and gives

${ }^{*}$ For a more detailed account compare Reighard 94, pp. 26-28. 
a smaller volume; in the smaller tube it stays up and yields a larger volume. Again the result varies with the character of the material. A diatomaceous plankton settles much more compactly than one consisting largely or entirely of Crustacea. If there is any considerable amount of filamentous material, like Lyngbya, or some of those forms, the plankton will not settle at all thoroughly, and the volume reached then will be much greater than is really represented. In the third place the amount obtained by the measurement depends upon the time which the plankton is allowed to settle, since I have had tubes standing up to two or three months and the plankton settled all the time, not regularly, but somewhat even to the end of the period. Finally the volume depends upon the conditions as regards movementwhether the tube be in absolute quiet or in a room where there is constant vibration. The amount of variation possible, $i . e$., the limit of accuracy in this method, will be discussed more fully in another paper.

The second or gravimetric method of determining the volume of plankton has been recently advocated by Zacharias (95). The material obtained in a single haul of the vertical net is brought with care on to a filter paper and thoroughly drained; while yet fresh and moist it is weighed. The amounts thus obtained, expressed in milligrams, afford the basis for comparison of different hauls. One great objection to this method is advanced by Zacharias himself. A complete drying out of the mass is impracticable and the amount of moisture which remains is undoubt. edly variable, being evidently greater in hauls of larger volume than in those which are scanty. Zacharias estimates the quantity of moisture held in the mass of plankton as one-fourth of the entire weight. No evidence is given to support this statement, neither is it discussed at all, and I cannot see that it has more weight than a purely personal opinion. Nor is it evident that greater accuracy is reached in this way than by the volumetric method. The second objection to this proceedure, however, is more weighty and absolutely prohibits its employment in many cases. The material obtained in the haul is entirely destroyed 
and cannot be used for subsequent qualitative examination of any sort, whereas the measurement of a haul by the volumetric method does not in the slightest injure the material or in any way interfere with future operations involving its use.

But beyond all these variations in the amount as determined by both methods, there is at least one source of error in the relation expressed by the actual figures. It is no infrequent matter to find in those hauls made from the bottom a certain amount of foreign material, sand, etc.; this is either stirred up when the bucket strikes the bottom, or, being carried along by currents, is swept into the net. It is, of course, preserved and measured with the true plankton material and falsifies the actual amount of the haul according to the value which may be included. In one case at least (Ward, 95, p. 248,) the amount of sand swept into a bottom haul by a current was sufficient to raise the total mass not less than one-third. The modification here suggested was evolved to meet this difficulty and to correct these errors.

The entire mass of plankton in a single haul is measured in a graduated tube, as in the volumetric method, and the volume recorded. A certain amount is then poured into an evaporating dish, care being taken that the entire mass of the haul has been thoroughly shaken up so that the different constituents are equally distributed through the volume. Ordinarily one-fifth to one-half of the original mass will be poured out, and the remainder is then carefully measured as before by the volumetric method and the volume noted. The portion of the plankton removed is next air-dried, weighed, then dried to a constant weight at $100^{\circ} \mathrm{C}$., and the amount recorded. The ash is next obtained and weighed, and finally by digestion with concentrated $\mathrm{HCl}$, washing, decanting and drying, the weight of the sand present is found.* To illustrate the method three hauls made in Lake Michigan are taken: $\mathrm{XIII}^{4}$ and $\mathrm{XIX}^{4}$ are partial hauls, free from impurities; and $\mathrm{XIX}^{5}$ is a bottom haul which was very much polluted

*The processes were very kindly carried out for me in the Chemical Laboratory of the University of Nebraska, by Mr. E. E. Nicholson, to whom my sincere thanks are due for his kindness. 
by sand. The results obtained are expressed in the following table :

\begin{tabular}{|c|c|c|c|c|c|c|c|c|c|}
\hline \multirow{3}{*}{$\begin{array}{l}\text { Number } \\
\text { of Haul. }\end{array}$} & \multirow{2}{*}{\multicolumn{2}{|c|}{$\begin{array}{c}\text { Depth in Metres } \\
\text { of }\end{array}$}} & \multirow{2}{*}{\multicolumn{2}{|c|}{$\begin{array}{c}\text { Volume in ec. of } \\
\text { Haul. }\end{array}$}} & \multirow{3}{*}{$\begin{array}{c}\text { Percentage } \\
\text { of Original } \\
\text { Volume } \\
\text { Taken as a } \\
\text { Sample. }\end{array}$} & \multicolumn{4}{|c|}{ Weight in Milligrams. } \\
\hline & & & & & & \multirow{2}{*}{$\begin{array}{c}\text { Air- } \\
\text { Dried } \\
\text { Sample }\end{array}$} & \multirow{2}{*}{$\begin{array}{l}\text { Conetant } \\
\text { Weightof } \\
\text { Sample. }\end{array}$} & \multirow{2}{*}{$\begin{array}{c}\text { Ash } \\
\text { in } \\
\text { Sample }\end{array}$} & \multirow{2}{*}{$\begin{array}{l}\text { Sand } \\
\text { in } \\
\text { Sample }\end{array}$} \\
\hline & Haul. & Water. & $\begin{array}{l}\text { Origi- } \\
\text { nally. }\end{array}$ & $\begin{array}{l}\text { After } \\
\text { removal. }\end{array}$ & & & & & \\
\hline & 2 & 3 & & & & 53 & 50 & 6 & 2.3 \\
\hline & & & & & & 6 & 5 & & \\
\hline $\mathrm{XIX}^{5}$ & 36 & 36 & 11.90 & 9.61 & 19.2 & 207 & 206 & 160.0 & 112.0 \\
\hline
\end{tabular}

From this table data with reference to the composition of the entire haul may be obtained by simple calculation. In this way we arrive at the results given in the next table.

\begin{tabular}{|c|c|c|c|c|c|c|c|c|c|}
\hline \multirow{2}{*}{$\begin{array}{l}\text { Number } \\
\text { of Haul. }\end{array}$} & \multicolumn{3}{|c|}{$\begin{array}{c}\text { Weight in Milligrams for } \\
\text { Entire Haul of }\end{array}$} & \multicolumn{4}{|c|}{$\begin{array}{c}\text { Percentage in Air-dried Sample } \\
\text { of }\end{array}$} & \multicolumn{2}{|c|}{$\begin{array}{l}\text { Weight in grams for } \\
\text { plankton under } \\
1 \text { sq. m. of surface. }\end{array}$} \\
\hline & $\begin{array}{l}\text { Air-Dried } \\
\text { Plankton. }\end{array}$ & Ash. & Sand. & $\begin{array}{l}\text { Organic } \\
\text { Material. }\end{array}$ & $\begin{array}{c}\text { Entire } \\
\text { Ash. }\end{array}$ & $\begin{array}{c}\text { Ash, not } \\
\text { Sand. }\end{array}$ & Sand. & $\begin{array}{l}\text { Air-dried } \\
\text { Material. }\end{array}$ & Ash. \\
\hline $\mathrm{XIII}^{4}$ & 110 & 16 & 4.8 & 85.7 & 14.3 & 10.7 & 3.6 & 1.9982 & 0.2860 \\
\hline $\mathrm{XIX}^{4}$ & 72 & 9 & 2.5 & 86.8 & 13.2 & 9.7 & 3.4 & 1.3050 & 0.1701 \\
\hline $\mathrm{XIX}^{5}$ & 1034 & 800 & 560 & 22.6 & 77.4 & 23.2 & 542 & 18.7064 & 14.4710 \\
\hline
\end{tabular}

From the average of $\mathrm{XIII}^{4}$ and $\mathrm{XIX}^{4}$ it appears that in an ordinary haul, comparatively free from foreign material, there is about 3.5 per cent. of silicious matter, Io per cent. of other earthy substances, chiefly calcareous, and 86 per cent. of organic material. The plankton is thus very nearly pure food matter.

If this be compared with the results given for XIX ${ }^{5}$, it will be seen that the latter haul contains an excess of sand equal to more than 50 per cent. of the total weight and an excess of total inorganic matter equal to 64 per cent. This is in itself sufficient proof of the contamination of the haul, a fact equally clearly established by microscopical investigation of the material. By this method, however, one can compute with considerable accuracy the amount of foreign matter present and thus obtain a correction by which the recorded volume of any haul may be reduced to the true volume.

The method is further applicable to those cases when the 
plankton does not settle readily or fully. Here a correction is found for the excess of volume over the true amount.

In other words the results obtained by the volumetric method may thus be controlled and corrected through the detection of errors due to false measurements, and of those due to the presence of foreign inorganic substances in the haul. The latter is not shown in any way by the simple volumetric or gravimetric method. At the same time a much more accurate idea of the true weight of the plankton is offered than by the gravimetric method, since there is no variable and uncertain quantum of moisture to be estimated. The method is further applicable in that number of cases when the plankton is also to be used for the qualitative examinations, since the part not weighed is entirely uninjured, and may be treated in any desired manner.

I have used this method further in determining the actual weight of the plankton in Lake Michigan, in order to ascertain in this way the actual amount of food material present in the water. Further details on the application of the method may be found in my forthcoming report on the plankton of Lake Michigan, to be published as a Bulletin of the Michigan Fish Commission. 


\section{PAPERS CITED.}

'94. Reighard, J. E.-A Biological Examination of Lake St. Clair. Bulletin of the Michigan Fish Commission, No. 4;60 pp., 2 plates and map.

95. Ward, Henry B - The Food Supply of the Great Lakes; and some Experiments on its Amount and Distribution. Proc. Am. Mic. Soc. Vol. XVII., pp. 242 to 255.

95. Zacharias, O.-Ueber die wechselnde Quantität des Plankton im Grossen Plöner See. Forschungsberichte aus der Biologischen Station zu Plön. Theil III., Seite 97-117. 